\title{
DIÁLOGO, RESPONSIO, IMITACIÓN: CLAVES ESTRUCTURALES DE LA ÉGLOGA I DE GARCILASO
}

\author{
SOLEDAd PÉREZ-Abadín BARRo \\ Universidade de Santiago de Compostela
}

El debate acerca de la identidad real de los protagonistas de la égloga I ha condicionado su interpretación desde los primeros comentarios hasta la crítica actual, en la que Rafael Lapesa (1948) instaura la tesis del desdoblamiento de Garcilaso en los dos pastores, Salicio y Nemoroso, ya planteada por Faria e Sousaㄹ. De aceptar

Recibido: 17/X/2009 Aceptado: 14/XII/ 2009

${ }^{1}$ Frente a las propuestas que identifican a los personajes de la égloga con Garcilaso, Boscán, Sá de Miranda, Antonio de Fonseca e Isabel Freire (A. Valbuena Prat, «Isabel Freyre en las 'Églogas' de Garcilaso», en Homenaje al Profesor Emilio Alarcos García, Universidad de Valladolid, vol. 2, 1965-1967, pp. 483492; A. Roig, «¿Quiénes fueron Salicio y Nemoroso?», Criticón, 4 (1978), pp. 1-36; E. Martínez López, «El rival de Garcilaso: 'esse que de mí s'está reyendo' (Égl. I. 180)», BRAE, 61 (1981), pp. 191-281); A. Prieto, «El mundo poético garcilasiano», en Imago Vitae (Garcilaso y otros acercamientos al siglo XVI), Universidad de Málaga, 2002, pp. 31-91, rebaten el criterio de sinceridad estudios como los de R. Ter Horst, «Time and the tactics of suspense in Garcilaso's Égloga Primera», MLN, 83 (1968), pp. 145-163; M. J. Woods, «Rhetoric in Garcilaso's First Eclogue», MLN, 84 (1969), pp. 143-155; F. Goodwyn, «New Light of the Historical Setting of Garcilaso's Poetry», HR, 46 (1978), pp. 1-22; D. H. Darst, «Garcilaso's Love for Isabel Freire: The Creation of a Myth», JHP, 3 (1979), pp. 261-268; N. Ly, "Garcilaso: une autre trajectoire poétique», 
estos presupuestos, la égloga se desarrollaría como un amplio soliloquio, emitido por una única voz poética que solo modifica el disfraz pastoril del nombre, para evocar diferentes momentos de una trayectoria sentimental con la misma mujer, Isabel Freire. Pero el presente artículo no pretende calibrar el grado de correspondencia del poema con los hechos lamentados ni con personajes verídicos, sino considerar la expresión lírica despojada de un valor referencial que cancelaría su autonomía como texto literario.

Una lectura ceñida a los versos revela un conjunto de estancias distribuidas en dos cantos, que entablan entre sí una relación dialogal. Frente al enfoque autobiográfico que reduce la égloga a un monólogo, pronunciado por un solo yo desde dos estados amorosos consecutivos, se impone su marco teatral, con dos interlocutores que acuden a un escenario para comunicarse sus cuitas en extensas intervenciones que remedan el diseño de los diálogos in utramque partem, común a una variante estructural del poema bucólico ilustrada por el idilio vi de Teócrito y por las bucólicas v y viII de Virgilio y II de Nemesiano. Este engranaje dramático individualiza a cada uno de los pastores, que adquieren entidad en esa conversación engastada en el marco narrativo a cargo de la voz autorial ${ }^{2}$.

Las líneas divisorias de la égloga perfilan una estructura que realza la ficción dialogal: tras el exordio se disponen dos parlamentos sucesivos que simulan un canto amebeo en el que un narrador presenta a los hablantes, marca la alternancia y pone fin a la representación dramática. Este esquema deriva de la bucólica viII de Virgilio, repartida entre el lamento de Damón y los conjuros de Alfesibeo, diálogo incardinado en un marco en el que falta el epílogo ${ }^{3}$.

B.Hi., 83 (1981), pp. 263-329; L. Iglesias Feijoo, «Lectura de la égloga I», en Garcilaso. Academia Literaria Renacentista IV, Universidad de Salamanca, 1986, pp. 61-82 y D. Heiple, Garcilaso de la Vega and the Italian Renaissance, The Pennsylvania State University Press, 1994, pp. 3-27. Más recientemente, M. C. Vaquero Serrano propone reemplazar a Isabel por Beatriz de Sá (Garcilaso: poeta del amor, caballero de la guerra, Madrid, Espasa-Calpe, 2002; «Dos mujeres en la vida de Garcilaso: Guiomar Carrillo y Beatriz de Sá», Per Abbat. Boletín filológico de actualización académica y didáctica, 1 (2006), pp. 103-112). Parece preferible admitir, con Rubio Árquez ("Garcilaso, égloga I: entre conflicto sentimental y escritura poética», en A. Cancellier et alii (eds.), Escritura y conflicto / Scrittura e conflitto: Actas del XXII Congreso Aispi / Atti del XXII Convegno Aispi, vol. 1, Madrid, Instituto Cervantes / Associazione Ispanisti Italiani, 2006, pp. 367-377), que el poeta expresa sus sentimientos a través de voces textuales, sin descartar el valor testimonial de los versos a la hora de establecer una cronología de las relaciones amorosas de Garcilaso, interpretada por B. Morros («La muerte de Isabel Freyre y el amor napolitano de Garcilaso. Para una cronología de sus églogas y de otros poemas», Criticón, 105 (2009), pp. 5-35).

2 Se crea así una doble realidad, de dos planos distintos, el canto del poeta y el de los pastores, que se fusionan a través de la imitación, puesta al servicio del arte de representar ( $\mathrm{N}$. Ly, «Garcilaso: l'effet de naturel. Pour une poétique du plaisir mimétique», Les Langues Néo-Latines, 303-304 (1997-1998), pp. 134160 [157-158]).

3 La condición modélica de la bucólica vIII ha sido notada en numerosos trabajos como los de M. J. Bayo, Virgilio y la pastoral española del Renacimiento (1580-1530), Madrid, Gredos, 1959; D. FernándezMorera, The Lyre and the Oaten Flute: Garcilaso and the Pastoral, London, Tamesis Books, 1982 y R. La- 
Ambos poemas se corresponden del siguiente modo:

\begin{tabular}{|l|l|}
\hline Virgilio, bucólica VIII & Garcilaso, égloga I \\
\hline introducción (1-5) & introducción (1-6) \\
\hline Dedicatoria al cónsul Polión (6-13) & Dedicatoria a don Pedro de Toledo (7-42) \\
\hline Versos de transición (14-16) & Versos de transición (43-56) \\
\hline Canto de Damón (17-61) & Canto de Salicio (57-224) \\
\hline Versos de transición (62-63) & Versos de transición (225-238) \\
\hline Canto de Alfesibeo (64-109) & Canto de Nemoroso (239-407) \\
\hline & Conclusión (408-421) \\
\hline
\end{tabular}

Frente a la heterogeneidad de los dos núcleos de la bucólica virgiliana, los cantos de Salicio y Nemoroso manifiestan una esencial equivalencia lograda a través de la expresión lírica de un asunto común, el amoroso. Cada pastor comunica sus afectos, desengaños y esperanzas desde un prisma subjetivo y elegíaco, que afecta igualmente a la visión del entorno e incluso a las mediaciones del yo poético ${ }^{4}$. Este discurso lírico combina en calculado equilibrio los tres géneros retóricos, con predominio del epidíctico, aplicado por Salicio para transmitir una imagen dual de Galatea, hermosa pero infiel, y por Nemoroso para proclamar la condición divina de Elisa. El propósito

pesa, La trayectoria poética de Garcilaso, en Garcilaso: estudios completos, Madrid, Istmo, 1985, así como en las ediciones de E. L. Rivers (Obras completas con comentario, Madrid, Castalia, 1981) y B. Morros (Obra poética y textos en prosa, Barcelona, Crítica, 1995). Estos estudios proponen otras fuentes: el idilio I de Teócrito y las endechas atribuidas a Mosco y a Bión; el Canzoniere de Petrarca, también considerado por A. J. Cruz, Imitación y transformación. El petrarquismo en la poesía de Boscán y de Garcilaso de la Vega, Amsterdam-Filadelfia, John Benjamins, 1988 y A. Gargano, «Il lugar di Garcilaso», en L. Chines (ed.), Il Petrarchismo. Un modelo di poesia per l'Europa, Roma, Bulzoni, vol. 1, 2006, pp. 495-510; la égloga Melisaeus (1491) de Pontano, lamento del pastor por la pérdida de su esposa Ariadna; la Arcadia (V, XI, XII) y Phyllis (piscatoria I) de Sannazaro, objeto esta última del detenido cotejo de V. Bocchetta, (Sannazaro en Garcilaso, Madrid, Gredos, 1976, pp. 84-112); I due pellegrini de Tansillo, en donde Alcino y Filauto lamentan, respectivamente, el desdén y la muerte de sus amadas; una de las églogas funerales (XI) de Alamanni (Opere toscane, 1532), en donde dos pastores lloran la muerte de Galatea por parto; Tirsi de Castiglione, que contiene las quejas de Iolas por el desdén de Galatea. Pueden añadirse las tres églogas de tema funeral contenidas en el Libro secondo degli Amori (1534) de Bernardo Tasso, Alcippo, Davalo y Egloga pescatoria (Rime, ed. de V. Martignone, Torino, Res, 2 vols., 1995). Entre las derivaciones de la égloga garcilasiana merecen destacarse, por su cercanía al modelo, la que Medina Medinilla dedica a la muerte de Isabel de Urbina, analizada por J. Matas Caballero («Claves compositivas de la Égloga en la muerte de doña Isabel de Urbina, de Pedro de Medina Medinilla», en Espada del Olvido. Poesía del Siglo de Oro a la Sombra del Canon, Universidad de León, 2005, pp. 73-95), y algunas de Barahona de Soto, tal como constata G. Cabello Porras (Barroco y cancionero. El desengaño de amor en rimas de Pedro Soto de Rojas, Universidad de Málaga, 2004, pp. 275-415). Véanse, para una visión de la poesía renacentista y, en particular, de la producción de églogas, A. Prieto, La poesía española del siglo XVI, Madrid, Cátedra, 1984, 1987, 2 vols. Y Á. Alonso, La poesía italianista, Madrid, Ediciones del Laberinto, 2002.

4 Rivers (Garcilaso de la Vega Poems. A Critical Guide, London, Grant \& Cutler-Tamesis Books, 1980, pp. 64-74) percibe el carácter elegíaco de ambos cantos y su relación con las elegías amorosa y funeral de Garcilaso, demostrada con el cotejo de algunos pasajes. Al imbricar el tema amoroso en el molde pastoril, Garcilaso asume la lección de Sannazaro, artífice de la renovación del género bucólico mediante un proceso de reducción al lirismo (A. Gargano, «L'egloga a Napoli tra Sannazaro e Garcilaso», en Con accordato canto. Studi sulla poesia tra Italia e Spagna nei secoli XV-XVII, Napoli, Liguori, 2005, pp. 181-201). 
deliberativo se canaliza hacia el movere como facultad ejercida sobre el entorno pastoril, la mujer ausente, destinataria de las apelaciones, y el propio pastor, que experimenta un proceso psicológico conducente a la resignación ${ }^{5}$. Con menor presencia, el género judicial se materializa en las inculpaciones de Galatea o a Lucina. Tal unidad de propósito falta en la bucólica VIII, escindida entre el lamento amoroso, con reproches a Nisa, de Damón, y los ensalmos de una hechicera, de claro tenor suasorio.

Aunque en la égloga I el plano sentimental desplaza a los hechos externos, un tenue hilo narrativo reconstruye lo acaecido en el transcurso del día de duración de la égloga, entre el amanecer y el ocaso, para enlazar los dos cantos en este marco común. A su vez, cada intervención rememora una historia pasada, condicionante del infortunio actual $^{6}$. Los movimientos de entrada y salida de los personajes, en un escenario situado en el paisaje pastoril, que al final del poema ocultan las sombras nocturnas, a modo de telón, acerca el poema a una representación dramática, para sugerir esa dimensión asociada al poema bucólico desde sus orígenes. Esta factura narrativa y teatral que sirve de soporte al lirismo no se advierte en la égloga viII de Virgilio, consistente en la yuxtaposición de dos cantos sin vínculos perceptibles.

El principio binario, rector del estilo compositivo de Garcilaso, se combina en la égloga I con una estética de contrastes, vertebradora de la estructura de la égloga y de su contenido ${ }^{7}$. Una dualidad básica opone los cantos de Salicio y Nemoroso por su materia, celos y muerte, que lleva aparejado un diferente tono expositivo, la queja y el lamento. A su vez, cada parte desarrolla dicotomías, que enfrentan a Galatea con la naturaleza, al yo o a Galatea con el rival, a Elisa con Lucina-Diana, al valle pastoril con el ultraterreno, a la belleza mundana con la muerte, al yo con el destino en el símil del ruiseñor despojado por el duro labrador, al locus amoenus con el locus eremus tras la partida de Elisa, a los ciclos naturales reparadores con el perpetuo dolor. Incluso en el exordio la humildad del propio canto realza la excelsitud de don Pedro de Toledo.

\footnotetext{
5 Para Woods (op. cit.) esa finalidad se hace especialmente evidente en el canto de Salicio, planteado como una argumentación de efecto persuasivo y emocional. S. Ghertman (Petrarch and Garcilaso, London, Tamesis, 1975) también considera el criterio retórico, que combina con la atención a las relaciones interestróficas y a los modelos conceptual, contextual y sintáctico al explicar la estructura de la égloga.

6 Este elemento, el tiempo, ha sido visto repetidamente como factor determinante de la organización y sentido de la égloga (Ter Horst, op. cit.; Ly, op. cit., pp. 312-313; G. Güntert, «Garcilaso, Égloga primera: la adopción de la distancia estética», en A. Vilanova (coord.), Actas del x Congreso de la AIH, Barcelona, PPU, vol. 1, 1992, pp. 443-456; Rubio Árquez, op. cit.; F. Madelpuech-Toucheron, «La inmediatez paradójica o la relación amorosa imposible en las églogas de Garcilaso de la Vega», Criticón, 97-98 (2006), pp. 123-136; «Revisión de una escritura canónica y aproximación a una poética original: la temporalidad en Garcilaso de la Vega», en P. Ruiz Pérez (ed.), Cánones críticos en la poesía de los Siglos de Oro, Vigo, Academia del Hispanismo, 2008, pp. 75-85).

7 Desde un punto de vista conceptual, esos contrastes se traducen en las tensiones direccionales que, para Segre («Análisis conceptual de la I égloga de Garcilaso», en Las estructuras y el tiempo, Barcelona, Planeta, 1976, pp. 163-184), polarizan el campo sémico del texto.
} 
Este binarismo estructural, que realza el esquema divisorio proveniente de la bucólica vIII, queda contrapesado por la actuación de numerosos nexos que conectan los dos núcleos principales, para perfilarlos como canto amebeo a través de ecos temáticos y formales, conforme al modelo responsivo de la bucólica v de Virgilio ${ }^{8}$, en donde el planto funeral de Mopso y la proclamación de Menalcas siguen un desarrollo paralelo, aunque antitético, jalonado por numerosas recurrencias léxicas y motivos coincidentes: al duelo general por la muerte (vv. 20-23) se contrapone la alegría por su divinización (vv. 56-59); de distinto modo, ambos hechos alteran el orden en el reino animal, que interrumpe su actividad (vv. 24-26) o reduce sus rivalidades a una concordia discors (vv. 60-61); el llanto universal (vv. 27-28) tiene como réplica la apoteosis (vv. 62-64); la semblanza de Dafnis (vv. 29-35) apunta a su futuro culto (vv. 65-71), y en ambos casos son mencionados sus devotos: «tu decus omne tuis» (v. 34), «Sis bonus o felixque tuis!» (v. 65) ${ }^{9}$ y los dioses Pales y Apolo (v. 35), Febo y Baco (vv. 66, 69); el paisaje yermo, por efecto de la muerte (vv. 36-39), se contrarresta con la enumeración que reconstruye el orden armónico (vv. 76-78), mientras que el rito funeral, que incluye el epitafio (vv. 3944) anuncia las ceremonias de glorificación (vv. 72-75, 79-80) ${ }^{10}$.

En mayor medida que la bucólica v, la égloga I difumina el juego dialógico entre las intervenciones consecutivas en los largos parlamentos, de doce estancias, carentes de la fluida alternancia de tramos más acordes con el patrón clásico, tales como los elogios de Tirreno y Alcino a sus respectivas amadas en la égloga III (vv. 305-368) ${ }^{11}$. Motivos, recursos, inflexiones tonales y proceso psicológico, todo ello tamizado por el tema amoroso común, diseña una simetría determinante de la complementariedad

8 Las responsiones pueden definirse como «repeticiones a intervalos de ciertos temas que van formando estructuras espirales o anulares y en los que la identidad de conceptos viene expresada no tanto por repeticiones cuanto que por variaciones verbales» (V. Cristóbal, Virgilio y la temática bucólica en la tradición clásica, Madrid, Universidad Complutense, 1980, p. 125). Se aplican en la bucólica v, en donde el discurso de Menalcas es complementario y responsivo de temas, motivos y palabras en relación al de Mopso, tal como nota Cristóbal, op. cit., pp. 308-309 y en su ed. de Virgilio, Bucólicas, Madrid, Cátedra, 1996, p. 151.

9 «entre los tuyos tú todo el ornato», «Sé bueno y fausto a los tuyos». El texto y la traducción proceden de la edición citada de V. Cristóbal.

10 Añádanse las numerosas reiteraciones, advertidas por R. Guerrini («Vos coryli testes. Struttura e canto nella v egloga di Virgilio», en Atti della Accademia Nazionale dei Lincei, Classe di Scienze morali, storiche e filologiche, 1973, pp. 683-694), que estudia el módulo compositivo (rahmentechnisch) de la égloga, modelo de las dos variedades de ringkomposition, a cornice y circular. Véase asimismo el esquema trazado por J. Van Sickle («Strutture interne di singole egloghe nel libro bucolico di Virgilio», Maia, 30 (1983), pp. 205212 [208]), que evidencia la rigurosa simetría de los cantos.

11 Derivados de un carmen amoebaeum, la bucólica vil de Virgilio, que a su vez, y mediatizada por Garcilaso, inspira los pasajes finales de las églogas i y viII de la Bucólica del Tajo de Francisco de la Torre (S. Pérez-Abadín Barro, «La Bucólica del Tajo de Francisco de la Torre como poemario pastoril: visión de conjunto», Criticón, 105, 1 (2009), pp. 85-116). Véase, para el canto amebeo o contrapunto en la tradición clásica, A. J. Vaccaro, Canto y contrapunto pastoril de Virgilio a Nemesiano. Estudio, versión y notas, Buenos Aires, Columba, 1974. Véase, para este tramo y para la estructura general del poema, A. Ramajo, «Munus Mariae: Garcilaso, égloga III», BRAE, 88 (2008), pp. 133-193. 
de los cantos, enlazados por la responsio. Garcilaso potencia esta técnica, encontrada en Virgilio $^{12}$, hasta convertirla en el principal resorte estructural de su poema, que en su segunda mitad avanza en continua remisión a la primera. La imagen visual de este desdoblamiento se traslada a la identidad de los dos pastores, que comparten el infortunio amoroso recíprocamente comunicado, sin que esta simetría implique un sustrato autobiográfico ${ }^{13}$.

\section{Estrofas 1-4, 17 y 30}

El marco narrativo de la égloga es enunciado por un yo poético, encargado de introducir su poema, presentar a cada interlocutor y cerrar la égloga, con comentarios de índole metapoética. La presencia de esta voz se percibe en el exordio (estrs. 1-4), en la transición (estr. 17) y en el epílogo (estr. 30), que combinan las referencias al canto, propio o de los pastores, con notas descriptivas del marco pastoril.

Desde el comienzo, se propone un discurso de naturaleza musical: «El dulce lamentar de dos pastores, / Salicio juntamente y Nemoroso, / he de cantar» (vv. 1-3), «escucha tú el cantar de mis pastores» (v. 42). Reaparecen estas menciones en las estrofas medial y última: «Aquí dio fin a su cantar Salicio», «Lo que cantó tras esto Nemoroso / decildo vos, Piérides» (vv. 225, 235-236), «ni fueran acabadas / las canciones» (vv. 409-410). Solo en el exordio el cantar se ofrece al destinatario, figura ausente de la transición y del epílogo.

El canto se identifica, hasta confundirse, con el lamento o el llanto: «El dulce lamentar» (v. 1), «y sospirando en el postrero acento, / soltó de llanto una profunda vena» (vv. 226-227), Filomena «dulcemente responde al son lloroso» (v. 234) ${ }^{14}$, «Nunca

\footnotetext{
${ }_{12}$ Aunque la crítica se ha fijado en la influencia de la temática funeral de la bucólica v (Bayo, op. cit., pp. 94-96; Bocchetta, op. cit., pp. 84-112; Lapesa, op. cit., p. 137; Morros, ed. cit., pp. 134-140), este poema no ha sido visto como modelo de la estructura responsiva de la égloga I de Garcilaso. Para la interpretación y análisis de esta bucólica, cfr. M. C. Putnam (Virgil's Pastoral Art. Studies in the Eclogues, Princeton University Press, 1970), Guerrini (op. cit.), Van Sickle (op. cit.), A. Salvatore («Lettura della quinta bucolica», en M. Gigante (ed.), Lecturae Vergilianae. Le bucoliche, Napoli, Giannini, 1988, pp. 198-223), R. Leclerqc (Le divin loisir. Essai sur les Bucoliques de Virgile, Bruxelles, 1996).
}

13 Dichas características reflejan la índole heterogénea de la égloga I, en conformidad con un modelo clásico de múltiples zonas de intersección con otros géneros. Véanse Cristóbal («Fronteras de la poesía bucólica virgiliana con otros géneros poéticos», en Los géneros literarios, Bellaterra, Universidad Autónoma de Barcelona, 1985, pp. 277-285 y «La poesía bucólica romana», Cuadernos de literatura griega y latina, 2 (1998), pp. 247-266, entre otros) y Leclerq (op. cit., pp. 78-94), para el concepto de bucólica virgiliana y sus principales leyes.

14 Cfr., para el mito de Filomela, A. M. Martín Rodríguez (El mito de Filomela en la literatura española, Universidad de León, 2008). El canto del ruiseñor reaparece en la estrofa 24: «que a su canto el aire suena» 
pusieran fin al triste lloro» (v. 408). De ahí resulta el efecto empático producido en el entorno, en los tres núcleos del marco narrativo: «cuyas ovejas al cantar sabroso / estaban muy atentas, los amores, / de pacer olvidadas, escuchando» (vv. 4-6), «queriendo el monte al grave sentimiento / de aquel dolor en algo ser propicio» (vv. 228-229), «la blanda Filomena, / casi como dolida / y a compasión movida» (vv. 231233), «las canciones que solo el monte oía» (v. 410). A la descripción del eco de la estrofa transicional remite el último ejemplo, del epílogo, indicio de la dimensión participativa de la naturaleza ${ }^{15}$.

No faltan los datos técnicos acerca del origen y facultades de la voz, que adopta la ambigua modestia de la tópica pastoril. En el exordio se declara el propósito, «sus quejas imitando» (v.3), y se reconoce la humildad de los versos ofrecidos, identificados con la hiedra que crece a la sombra del laurel, emblemático de la gloria del protector, al que se promete un futuro poema «antes que me consuma» (v. 27). La estrofa central reincide en la humilitas al invocar a las musas, «decildo vos, Piérides» (v. 236), aduciendo incapacidad: «que tanto / no puedo yo ni oso, / que siento enflaquecer mi débil canto» (vv. 236-238). Al igual que en los versos virgilianos amplificados ${ }^{16}$, se proclama aquí la naturaleza divina de la égloga, inspirada por las musas.

Las tres apariciones de la voz narrativa jalonan la égloga para reconstruir su percepción cronotópica. Dos indicios del oficio pastoril, las ovejas (v. 4) y el ganado (v. 420), marcan el comienzo y el final del poema en núcleos que anulan el paso del tiempo en una suerte de suspensión que alcanza a las ovejas, olvidadas de pacer (vv. 4-6), y al destinatario, a la espera de un canto en su honor ( «En tanto que este tiempo que adevino [...] escucha tú el cantar de mis pastores», vv. 29-42), hasta que este adormecimiento resultante del ingreso en la ucronía bucólica llega a su fin en la estancia de cierre («y recordando / ambos como de sueño», vv. 417-418). La duración del poema se mide por las indicaciones del momento del día, desde el amanecer de la introducción hasta el ocaso del epílogo: «Saliendo de las ondas encendido, / rayaba de los montes el altura / el sol» (vv. 43-45), «si mirando las nubes coloradas, / al tramontar del sol orladas de oro, / no vieran que era ya pasado el día; / la sombra se veía / venir corriendo apriesa / ya por la falda espesa / del altísimo monte» (vv. 411-417). Aunque la estrofa medial omite los datos cronológicos, la longitud idéntica de doce estrofas y la alternancia de los cantos permite situarla en la mitad del día.

(v. 333), a su vez relacionada con la estrofa 4: «él, con canto acordado / al rumor que sonaba / del agua que pasaba» (vv. 49-51), muestra de la sintaxis imitativa de la música del agua (N. Ly, La poésie castillane de la fin du Moyen Âge au début du Siècle d'Or, Paris, Messene, 1998, p. 63).

15 Esta dimensión órfica surge de nuevo en las estancias 15, 24 y 27. Cfr. Cruz (op. cit., pp. 102-106).

16 «non omnia possumus omnes» (VIII, v. 63) [«no todos a todo alcanzamos»]. 
El binarismo enlaza estos tres tramos en boca del yo poético, en la propositio: «El dulce lamentar de dos pastores, / Salicio juntamente y Nemoroso» (vv. 1-2), en la estrofa de convergencia de los cantores: «Aquí dio fin a su cantar Salicio [...] / Lo que cantó tras esto Nemoroso» (vv. 225, 235) y al final: «ambos» (v. 418). Se define así el principio dual de un poema en el que la materia se bifurca para replegarse sobre sí misma mediante un sistema de reiteraciones determinante de la equivalencia de los núcleos. Mientras que el canto de Salicio avanza incorporando nuevos topoi y recursos en el desarrollo de la materia amorosa y bucólica, Nemoroso elabora su discurso a partir de la recuperación de los elementos enunciados por su predecesor, a modo de reflejo simétrico en el que las estancias se corresponden. Esta estructura responsiva se incorpora a una cornice asimismo trabada por recurrencias que refuerzan la imagen de circularidad sugerida por los cantos.

\section{Estancias 5 y 19}

Salicio (estr. 5) emite en presente sus quejas contra Galatea, vilipendiada a través de imágenes y contrastes (mármol, fuego, nieve) que la definen dentro de los estereotipos petrarquistas, a los que también se adapta la actitud del pastor, que en el estribillo cambia la flauta pastoril de la bucólica vIII por las lágrimas («Incipe Maenalios mecum, mea tibia, uersus», «Salid sin duelo, lágrimas, corriendo» ${ }^{17} \mathrm{y}$ define su dolor en términos de muerte y de complacencia en el vasallaje hacia su señora. Esta primera estancia de la intervención de Salicio contiene el enunciado de la causa, en la que el abandono de la amada explica el rechazo de la vida: «Estoy muriendo, y aun la vida temo; / témola con razón, pues tú me dejas, / que no hay sin ti el vivir para qué sea» (vv. 60-62). Apenas se sugiere un tema, los celos, que adquirirá nitidez a medida que el canto progresa y revela la existencia de un rival.

Análogas competencias cumple la segunda estancia del parlamento de Nemoroso (estr. 19), que expone el motivo del lamento: «iOh tela delicada, / antes de tiempo dada / a los agudos filos de la muerte!» (vv. 260-262), primera alusión al fallecimiento prematuro de Elisa, que se detallará en la estancia 27. Ese hecho provoca el deseo de muerte, que Nemoroso comparte con su interlocutor: «Más convenible fuera aquesta suerte / a los cansados años de mi vida» (vv. 263-264). Se introduce así un tema recurrente en este canto configurado como elegía funeral en la que la superación del dolor genera el desprecio del mundo («y lo que siento más es verme

17 «Flauta, comienza conmigo a entonar estos versos menalios». El exhorto a las lágrimas contiene un complemento modal, «sin duelo», que ha sido visto como un recurso para alargar el verso (C. V. Aubrun, «Salid lágrimas...», B.Hi., 60 (1958), pp. 505-507) o bien como un anuncio de inminente muerte (B. Dutton, «Garcilaso's Sin duelo», MLN, 80 (1965), pp. 251-258). 
atado / a la pesada vida y enojosa», vv. 292-293) y la esperanza en la propia muerte como medio de liberación y reencuentro con la amada («hasta que muerte el tiempo determine / que a ver el deseado / sol de tu clara vista me encamine», vv. 321-323). Aunque Nemoroso también rinde vasallaje a Elisa, según se advierte, ya en la estancia 20 , en la descripción de sus ojos, que «llevaban tras sí, como colgada, / mi alma» (vv. 268-269), y de su mano, «llena de vencimientos y despojos» (v. 271), nunca le dirige reproches. De ahí que la exclamación recriminatoria contra Galatea, «¡Oh más dura que mármol», se desvíe en la estancia 19 hacia el destino adverso: «¡Oh bien caduco, vano y presuroso!» (v. 256), «¡Oh miserable hado! / ¡Oh tela delicada» (vv. 259-260). Se equiparan así la condena del comportamiento femenino con la futilidad de la existencia terrena, que en el planto de Nemoroso se perfilará hasta plantearse como una propuesta de trascendencia.

A esta pareja se adjunta la estancia 7, que tras un símil parentético (estr. 6), prosigue el vituperio de Galatea, aduciendo la propia muerte como argumento conmovedor: «de que por ti Salicio triste muera» (v. 87), «causar la muerte de un estrecho amigo» (v. 94), «Si en pago del amor yo estoy muriendo» (v. 96). A su vez, la obsecratio a Dios (vv. 91-95) anuncia los reproches a una divinidad pagana, Lucina, en la estancia 27, por permitir la muerte de Elisa ${ }^{18}$.

\section{Estancias 6 y 23}

El transcurso del día, medido por la salida o la puesta del sol, presta un referente al estado de ánimo en ambos cantos. Salicio (estr. 6) describe el despertar general recurriendo a tres órdenes, «las aves y animales y la gente» (v. 73), implicados en una correlación reiterativa que ocupa la fronte y parte de la sirima (vv. 71-80) ${ }^{19}$. El yo se incardina en esa enumeración a través de la priamel ${ }^{20}$, en la que ocaso y amanecer cobran sentido metafórico: «siempre está en llanto esta ánima mezquina, / cuando la sombra el mundo va cubriendo, / o la luz se avecina» (vv. 81-83). Se aplica de este modo el contraste petrarquesco entre el efecto renovador de los ciclos naturales y el permanente sufrimiento del yo, única anomalía en esa ley universal. A esta estrofa se retrotrae la representación del dolor de Nemoroso como un anochecer al que seguirá la luz del reencuentro con Elisa (estr. 23). En este caso, el ejemplo de la naturaleza sugiere

\footnotetext{
18 Ambas comparten la enálage de persona gramatical: «de que por ti Salicio triste muera» (v. 87), «que siempre aflige esta ánima mezquina» (v. 368).

19 Figura denominada distribución o merismós en las Anotaciones (1582) de Herrera (Anotaciones a la poesía de Garcilaso, ed. de I. Pepe y J. M. Reyes, Madrid, Cátedra, 2001, p. 704).

20 Para la priamel o praeambulum, véase W. H. Race (Classical Genres and English Poetry, London-New York-Sydney, Groom Helm, 1988, pp. 35-55).
} 
una estructura comparativa (Como... tal) del entorno y la subjetividad, que cifrará en ese normal devenir la esperanza de recobrar a la amada tras la muerte. El contraste cromático del espectáculo celeste se prolonga en la segunda parte del símil (tal) en dos imágenes, la «tenebrosa / noche de tu partir» (vv. 318-319) y el «deseado / sol de tu clara vista» (vv. 322-323), que culminan el proceso de identificación del yo con el entorno ${ }^{21}$.

Por caminos divergentes, el contraste y la analogía, y simétricos, el binomio día-noche ha plasmado los sentimientos de cada cantor, recurriendo a elementos descriptivos comunes, pues los versos de Salicio: «El sol tiende los rayos de su lumbre» (v.71), «cuando la sombra el mundo va cubriendo / o la luz se avecina» (vv. 82-83), tienen su eco en los de Nemoroso: «Como al partir del sol la sombra crece, / y en cayendo su rayo, se levanta / la negra escuridad que el mundo cubre» (vv.310-312), «hasta que el sol descubre / su luz pura y hermosa» (vv. 316-317), «de sombra y de temor atormentado» (v. 320).

\section{Estancias 8 y 18-19}

La amada condiciona la percepción de una naturaleza que aquilata su amenidad al asociarse a su imagen o, de otro modo, el escenario se convierte en el locus amoenus cuando acoge la presencia de Galatea o Elisa ${ }^{22}$. Tal sintonía se refiere al pasado, ya que el presente de ruptura o pérdida se proyecta también sobre el paisaje para invertir sus connotaciones subjetivas.

La estancia 8 combina diestramente los recursos retóricos para sugerir un valle perfecto a los ojos del contemplador, según hace explícita la triple anáfora de «por ti» que relaciona la descripción con esa destinataria incorporada al significado de la naturaleza. El sintagma preposicional que implica a la amada preside y limita una enumeración regida por un orden paralelístico flexible: cada uno de los pies de la fronte concluye con un verbo en pasado, «agradaba»y «deseaba», al que precede una serie de frases nominales que funcionan como sujeto (vv. 99-101) o complemento directo (vv. 103-105). El primer núcleo selecciona las cualidades, «silencio»y «esquividad y apartamiento», seguidas de sendos modificadores preposicionales, «de la selva

${ }_{21}$ C. Guillén (Literature as System, Princeton University Press, 1971, p. 186) advierte en la estrofa 23 la dimensión metafísica de la luz y la noche.

22 Para este tema, véase A. Gargano, que plantea la doble perspectiva temporal del topos en «'Questo nostro caduco et fragil bene'. Il locus amoenus nell'Egloga I di Garcilaso», en G. Calabrò (ed.), Signoria di parole. Studi offerti a Mario di Pinto, Napoli, Liguori, 1998, pp. 283-298. 
umbrosa» y «del solitario monte», en los que se menciona el paisaje ${ }^{23}$. Se infiere de estos versos una valoración de las ventajas espirituales del lugar, que proporciona tranquilidad de ánimo. En cambio, el segundo tramo realza los aspectos sensoriales del paisaje, acelerando el ritmo enumerativo para acumular cinco elementos, dos en cada verso, compuestos por epíteto y sustantivo, en tres casos precedidos de artículo: «la verde hierba, el fresco viento, / el blanco lirio y colorada rosa / y dulce primavera» (vv. 102-104) ${ }^{24}$. De este modo, las frases de andadura morosa, correspondientes a la paz bucólica, dejan paso a un movimiento más ágil, acorde con el disfrute hedonista, según refleja el siguiente esquema ${ }^{25}$ :

$$
\begin{aligned}
& \text { Por ti }+ \text { fn. [art. }+ \text { sust. }+ \text { fprep. }(\text { de }+ \text { art. }+ \text { sust. }+ \text { adj. })] \\
& \text { por } \left.\mathrm{ti}+\text { fn. [art. }+ \text { sust. }_{1} \text { y sust. }_{2}+\text { fprep. }(\text { de }+ \text { art. }+ \text { adj. }+ \text { sust. })\right]
\end{aligned}
$$

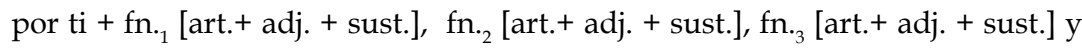

$$
\begin{aligned}
& \text { fn. }{ }_{4} \text { [adj. + sust.] y fn. }{ }_{5}[\text { adj. }+ \text { sust.] }
\end{aligned}
$$

La omisión del determinante en los dos últimos sintagmas podría interpretarse como un recurso de cohesión de tres elementos bajo un artículo común, así representado:

$$
\begin{aligned}
& \text { por ti }+ \text { fn. }_{.1} \text { [art. }+ \text { adj. }+ \text { sust.], fn. } ._{2} \text { [art. }+ \text { adj. }+ \text { sust.], fn. } ._{3} \text { [art. }+ \text { adj. }+ \text { sust. y adj. } \\
& + \text { sust. y adj. + sust.] }
\end{aligned}
$$

El equilibrio y armonía con la naturaleza, que realza el paralelismo constructivo, se altera en la sirima mediante la auersio: «¡Ay, cuánto me engañaba! / ¡Ay, cuán diferente era / y cuán de otra manera / lo que en tu falso pecho se escondía!» (vv. 105-108). A partir de esta inflexión tonal y estilística, también marcada por la anáfora y el isocolon, la perspectiva se sitúa en el presente de desengaño, desde el que se desenmascara la falsedad de la amada y se recuerdan los agüeros de la «siniestra corneja» (v. 110).

Nemoroso da comienzo a su canto con una apelación a los elementos del valle, descritos e interpretados en estancias consecutivas (18-19). La fronte de la primera evoca un escenario trazado con pinceladas que seleccionan constituyentes emblemáticos del

\footnotetext{
${ }_{23}$ De ahí que R. Poggioli (The Oaten Flute. Essays on Pastoral Poetry and the Pastoral Ideal, Cambridge, Massachusetts, Harvard University Press, 1975, pp. 182-193) aduzca esta estrofa, con la 21, como muestra de la actitud pastoral clásica ante la soledad.

${ }^{24}$ El bimembre «el blanco lirio y colorada rosa» aporta un matiz moral al contraste cromático, semejante al del soneto XXIII («En tanto que de rosa y azucena»).

25 A lo largo de este trabajo se recurre a esquemas sintácticos para explicar la estructura de determinados pasajes, en un intento de aplicar un método formalista que refleja el perfecto engranaje de los elementos gramaticales (Cfr. E. Alarcos, El fruto cierto. Estudios sobre las odas de fray Luis de León, pról. de A. Blecua, ed. de E. Martínez Mata, Madrid, Cátedra, 2006).
} 
locus amoenus: el agua cristalina ${ }^{26}$, los árboles, el prado umbrío, las aves y la hiedra, para trabarlos entre sí en dinámicas asociaciones, ya que los árboles se reflejan en el agua, proporcionan sombra, son recorridos por la hiedra y, del mismo modo, se infiere que sirven de refugio a las aves, cuyos trinos o «querellas» (v. 242) aportan la nota afectiva de este paisaje que parece cobrar vida. El signo positivo de la estampa natural aproxima las fronti de las estancias 8 y 18, que también comparten la referencia a la sombra y los adjetivos verde y fresco, para confirmar la pertinencia del espacio pastoril diseñado en la presentación de Salicio (estr. 4), que se ubica en un «fresco y verde prado» (v. 48) atravesado por «una agua clara» (v. 47). Coinciden asimismo en la aplicación del paralelismo, que en la estancia 18 unifica la serie de cinco apóstrofes, dispuestos según este esquema:

$$
\begin{aligned}
& \mathrm{fn}_{._{1}} \text { [adj. + sust. + adj., adj.] } \\
& \mathrm{fn}_{._{2}} \text { [sust. + adj. (que + cláus.)] } \\
& \mathrm{fn}_{._{3}} \text { [adj. + sust. + adj. (adj. + fprep.)] } \\
& \mathrm{fn}_{._{4}} \text { [sust. + adj. (que + cláus.)] } \\
& \mathrm{fn}_{._{5}} \text { [sust. + adj. (que + cláus.)] }
\end{aligned}
$$

Prosigue la estancia 18 con una valoración afectiva del paisaje, recinto del apartamiento, el reposo y la alegría. Nemoroso retoma los versos de Salicio: «por ti la esquividad y apartamiento / del solitario monte me agradaba» (vv. 100-101), al reconocer, apelando a los elementos: «con vuestra soledad me recreaba» (v. 248). Amplifica la idea con el detalle del sueño («donde con dulce sueño reposaba», v. 249), conforme a las versiones clásicas del epodo II de Horacio y de la égloga I de Virgilioº ${ }^{27}$. El recuerdo de la amada depositado en el paisaje («por donde no hallaba / sino memorias llenas de alegría», vv. 251-252) reproduce el efecto de los anafóricos por ti de la primera intervención.

El «grave mal», apenas insinuado (v. 246), se amplifica en la estrofa 19, que además de oponerse a la precedente encierra un doble contraste que la divide. La fronte constata el paso de la felicidad a la tristeza y la presencia de Elisa al despertar, dentro de las coordenadas de un espacio invariable, el valle, y un tiempo captado en

\footnotetext{
26 El comienzo «Corrientes aguas puras, cristalinas» imita la canción de Petrarca «Chiare, fresche e dolci acque» (CXXVI), con imágenes de Ariosto (Morros, ed. cit, pp. 132, 465).

27 Los versos «somnos quod inuitet leuis» («invita / a dormitar dulcemente», Horacio, epodo II, v. 28) $\mathrm{y}$ «saepe leui somnum suadebit inire susurro» («te invitará muchas veces al sueño con suave susurro», Virgilio, bucólica I, v. 55) inspiran los de la égloga II de Garcilaso: «Convida a un dulce sueño» (v. 64) y de la oda I de Fray Luis: «Un no rompido sueño» (v. 26). Véanse en las ediciones citadas de Virgilio y Garcilaso y en Horacio, Odas y Epodos, ed. de M. Fernández-Galiano y V. Cristóbal, Madrid, Cátedra, 1990; L. de León, Poesía, ed. de A. Ramajo Caño, Barcelona, Galaxia Gutenberg-Círculo de Lectores, 2006.
} 
su devenir, con el matiz moral de la exclamación «iOh bien caduco, vano y presuroso!» (v. 256), dispuesta a modo de auersio en medio de la estrofa. A este tramo, en esencia positivo por el predominio del pasado, sigue una sirima que comienza con una nueva auersio, lamentos exclamativos, contra el destino causante de la muerte prematura, seguidos de la manifestación del anhelo de la propia muerte. Esta quiebra medial aproxima la estructura de las estancias 8 y 19, a las que se une la 25, tercer caso de auersio exclamativa al comienzo de la sirima («iAy, muerte arrebatada», v. 344). A pesar de su bivalencia y sus contrastes internos, la estancia 19 pone énfasis en la desposesión del presente, para ofrecer así el reverso de esa realidad del valle ameno descrito en la precedente. Reproduce, por lo tanto, el juego que mantienen los dos segmentos de la estancia 8.

De este núcleo irradian posteriores referencias al locus amoenus, en el canto de Nemoroso siempre ligado a la compañía de Elisa, en el pasado en la estancia 21: «cuando en aqueste valle al fresco viento / andábamos cogiendo tiernas flores» (vv. 283-284) y en el futuro en la estancia 29: «y en la tercera rueda, / contigo mano a mano, / busquemos otro llano, / busquemos otros montes y otros ríos, / otros valles floridos y sombríos» (vv. 400-404). Esta visión ultraterrena aporta la paz espiritual perdida tras la muerte de Elisa, según denotan las recurrencias de reposar o descansar: «donde con dulce sueño reposaba» (v. 249), «me entristezco y me canso en el reposo» (v. 254), «estuve ya contento y descansado» (v. 255), «donde descanse y siempre pueda verte» (v. 405). El último ejemplo muestra que esa quies connota la presencia de la amada, en la restauración de aquel episodio añorado en la estancia 19: «Acuérdome, durmiendo aquí algún hora, / que, despertando, a Elisa vi a mi lado» (vv. 257-258).

\section{Estrofas 9 y 19}

La dimensión onírica del poema se advierte ya en la estancia 9, en donde Salicio

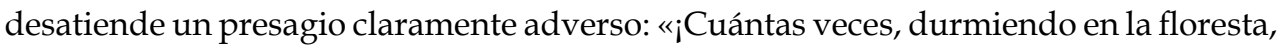
/ reputándolo yo por desvarío, / vi mi mal entre sueños, desdichado!» (vv. 113-115). Como en los versos de Nemoroso que evocan el despertar en compañía de Elisa (vv. 257-258), el sueño de Salicio simboliza una pérdida, la de Galatea que huye como el agua, en esta recreación del mito de Tántalo ${ }^{28}$. Cada imagen es portadora de un valor

${ }_{28}$ En «Garcilaso: une autre trajectoire poétique» (p. 298), Ly asimila la huida del agua a la huida sentimental, tal como muestra la equivalencia semántica entre «el curso enajenado» (v. 124) y «Cuando tú enajenada» (v. 147), ya en la estancia 11. Frente a las lecturas de la estancia 9 más generalizadas, S. Zimic («Las églogas de Garcilaso de la Vega: ensayos de interpretación», BBMP, 64 (1988), pp. 5-107 [7-8]) rechaza el valor premonitorio de las pesadillas, que reflejan, según él, las aprehensiones e inseguridad de Salicio acerca del cariño de Galatea. 
premonitorio de signo inverso, pues la amada de Salicio en efecto lo abandonará, mientras que Elisa volverá a aparecer al despertar Nemoroso en el valle paradisíaco del círculo de Venus.

\section{Estrofas 10 y 20}

Cada canto esboza un retrato de la amada a partir de rasgos similares, concordantes con el canon de belleza petrarquista, en sendas estrofas $(10,20)$ que comparten la configuración interrogativa y anafórica para realzar el sentimiento de desposesión. En la estrofa 10, la fronte enumera los atributos de Galatea (habla, ojos, fe, brazos) combinando la anáfora con el paralelismo, dentro de una estructura interrogativa que permite confrontar las tres personas gramaticales implicadas en esta situación amorosa ${ }^{29}$. Predominan los enunciados en los que la segunda persona, en forma de frase nominal con determinante posesivo, queda fuera de la pregunta, que inquiere acerca de ese rival, representado por un pronombre genérico (cúya, quién, dó, cuál):

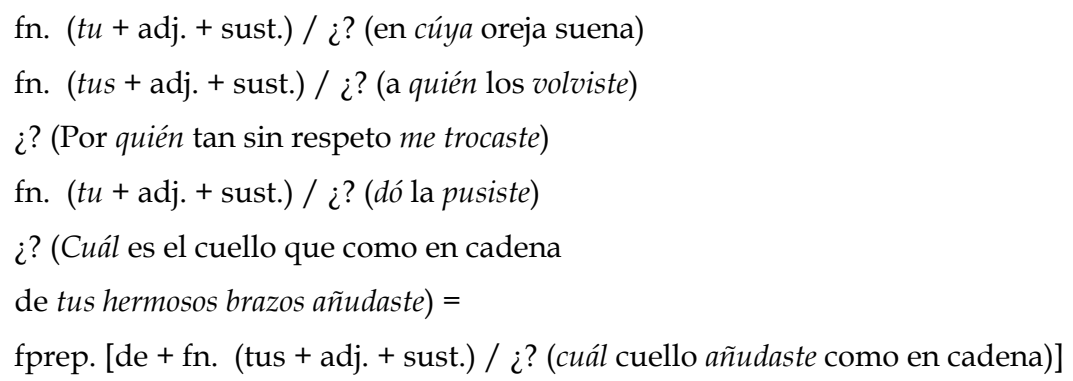

Las variaciones de esa estructura evitan el efecto repetitivo sin alterar el juego gramatical que denuncia la intromisión del rival. Por eso, con el esquema principal, que interroga en dos tiempos acerca de cada rasgo de Galatea, alternan las preguntas que abarcan todo el verso, con alcance general («¿Por quién tan sin respeto me trocaste?», v. 129) o bien como modificación alternativa del esquema básico subyacente, frase nominal con posesivo, seguida de pregunta, para así cerrar la serie.

Ese tono de reproche, enfatizado por los insistentes verbos de segunda persona que cierran casi todas las cláusulas, se depone en la segunda parte de la estancia, para ceder su lugar a la melancolía implícita en las imágenes de la hiedra y el muro o la parra y el olmo, anticipadas por el símil «como en cadena» (v. 131) relativo al abrazo. Se anula

${ }_{29}$ Rivers (Garcilaso de la Vega Poems, p. 67; ed. cit., p. 277) relaciona esta serie de interrogaciones con la oda «Quis multa gracilis» (I, v) de Horacio. 
al mismo tiempo la tensión pronominal, pues desaparecen las apelaciones, relevadas por el discurso ensimismado del yo, que convierte un emblema clásico de la armonía amorosa $^{30}$ en imágenes de desgarro, cuya fuerza se concentra en el determinante «otro» que acompaña a «muro» y a «olmo», para designar al rival que lo ha desplazado.

Nemoroso vuelca su dolor por la muerte de Elisa en una estrofa vertebrada por el insistente ubi sunt, en una quíntuple formulación que tendrá respuesta en los tres últimos versos ${ }^{31}$. Cada uno de los enunciados confronta la belleza del pasado con la inanidad del agora, aportando así un matiz moral al contenido esencialmente amoroso del duelo fúnebre. De nuevo el paralelismo anafórico se presta a combinaciones flexibles, sin alterar el principio rítmico que las unifica, el reiterado «¿Dó está(n) (agora)» que preside la evocación de rasgos físicos de la amada, descritos en su belleza y por el efecto ejercido en el contemplador, el propio hablante.

$$
\begin{aligned}
& \text { ¿Dó están agora + fn. [det. + adj. + sust. + adj. (que + cláus.)] } \\
& \text { ¿Dó está + fn. [det. + adj. + sust. + adj. / adj. (adj. + fprep.) / adj. (que + cláus.)] } \\
& \text { fn. [det. + sust. + adj. (que + cláus.)] + adónde están = } \\
& \text { ¿adónde están + fn. [det. + sust. + adj. (que + cláus.)] } \\
& \text { adónde + fn. [det. + adj. + sust.] } \\
& \text { ¿Dó + fn. [det. + sust. + adj. (que + cláus.)] }
\end{aligned}
$$

Con los presentes de la fórmula interrogativa se confrontan los imperfectos del recuerdo expresado en las clásulas de relativo, que en tres de las preguntas acompañan al sustantivo. Estos verbos en un pasado sin concluir proporcionan un primer indicio de la caducidad confirmada en la respuesta. Mientras que los dos pies de la fronte guardan una semejanza constructiva casi rigurosa, que revalida la implicación de la primera persona, «mi alma» (v. 269) y «mis sentidos» (v. 272), la sirima altera el orden de los elementos para segmentar la pregunta en dos secciones, enunciativa e interrogativa, según el modelo aplicado en la estrofa 10. Queda así realzada la parte central de la estrofa, un grupo de tres heptasílabos que pone en paragón los cabellos

\footnotetext{
30 Estudia la historia de este topos P. Demetz («The Elm and the Vine: Notes Toward the History of a Marriage topos», PMLA, 73 (1958), pp. 521-532). Cfr. Morros (ed. cit., p. 462).

31 Esta estrofa, cuyo inicio evoca el soneto «Ov' è la fronte» (CCXCIX), acumula reminiscencias de Petrarca, localizadas desde los primeros comentaristas (véanse Rivers, ed. cit., p. 289; Fernández-Morera, op. cit., p. 48; Lapesa, op. cit., pp. 133-134; Morros, ed. cit., pp. 133, 465-466). Para la anomalía métrica de la estancia, notada por Herrera y Tamayo de Vargas (Rivers, ed. cit., p. 290), véase, fundamentalmente, D. Fernández-Morera («On Garcilaso's Égloga I and Virgil's Bucolic VIII», MLN, 89 (1974), pp. 273-280), que la atribuye al propósito de reproducir la diferencia cuantitiva de los hexámetros de la bucólica viII. Véase también M. P. Manero Sorolla, Imágenes petrarquistas en la lírica española del Renacimiento. Repertorio, Barcelona, PPU, 1990 y «La configuración imaginística de la dama en la lírica española del Renacimiento: la tradición petrarquista», BBMP, 68 (1992), pp. 5-71.
} 
con el sol. La elipsis de estar, en las dos últimas preguntas, cohesiona la serie, que comparte además el agora solo formulado con la primera.

Ese agora común se proyecta en el tramo final, que da respuesta en presente al cúmulo de interrogantes, reducidos a un todo abarcador en el que el deíctico de distancia en el tiempo, en «aquellos claros ojos» (v. 267), se convierte en un señalador de proximidad, física y temporal: «Aquesto todo agora ya se encierra» (v. 279), que apunta a la sepultura como reducto material de la belleza caduca. Aflora de nuevo la primera persona, "por desventura mía» (v. 280)32, una vez más determinada por el posesivo, antes de la mención del lugar en que yace Elisa: «en la escura, desierta y dura tierra» (v. 281). Frente a los epítetos connotadores de luminosidad y pureza desgranados en la descripción (claros, blanca, delicada, blanco, dorado, graciosa), la terna de adjetivos incide en las notas negativas asociadas a la muerte, a efectos materiales equivalente a la tumba, «la escura, desierta y dura tierra» (v. 281) ${ }^{33}$.

Entre ambas estrofas se tienden conexiones semánticas, afectivas y retóricas, que refrendan su equivalencia funcional, pues en el proceso psicológico de cada uno de los pastores este énfasis interrogativo traduce la rebeldía ante la pérdida de la amada, ahora junto a otro hombre o sepultada. Si hasta ese momento el canto solo había insinuado la causa del lamento, en estas estrofas se exponen abiertamente la existencia de un rival y el fallecimiento. A pesar de la ausencia de detallismo de la descripción, se supone entre ambas mujeres una semejanza física, acorde con el estereotipo petrarquista, según confirma el único elemento coincidente, los «claros ojos». El pastor ha sido despojado de esos atributos, que se evocan como reliquias y sugieren la noción de violencia, plasmada en los verbos «arrancada» (v. 136) y «encierra» (v. 279). Y aunque el canto de Salicio está desprovisto de connotaciones funerales, el final de esta estrofa hace referencia a la muerte propia como fin del sufrimiento: «que no se esté con llanto deshaciendo / hasta acabar la vida» (vv. 138-139).

El modo interrogativo que comparten ambas estancias se prolonga a las siguientes, la 11 («¿Qué no se esperará de aquí adelante?») y la 21 («¿Quién me dijera, Elisa, vida mía?»), para disponer así en parejas de estrofas la manifestación de la incredulidad y la rebeldía ante el destino adverso. Las consecuencias de la pérdida de la amada, que lamentan en forma de pregunta las estancias previas, se definen ahora en términos de desposesión, convertida en ley general («que el más seguro tema con recelo / perder lo que estuviere poseyendo», vv. 151-152) o interiorizada como estado espiritual («solo, desamparado, / ciego, sin lumbre en cárcel tenebrosa», vv. 294-295).

32 Cfr., en el canto de Salicio, «la desventura mía» (estr. 8, v. 111).

33 El tema de la muerte en la tradición pastoril es analizado en el capítulo «The Funeral Elegy» de Pogglioli (op. cit., pp. 64-82). 


\section{Estancias 12 y 22}

Para plasmar el alcance universal de la ruptura amorosa se contempla la alteración del entorno por efecto de la infidelidad o de la muerte, en sendas estancias que varían la idea del mundo al revés, respectivamente plasmada como enumeración de adynata y como metamorfosis. Tras el vaticinio de la estrofa 11, Salicio constata la quiebra de las leyes de la concordia en una serie de impossibilia en la que se incardina la pareja de Galatea y su amante, por medio de un movimiento pendular entre lo general y lo particular ${ }^{34}$ : la elección de Galatea sienta un precedente, que servirá de ejemplo a otros órdenes de la naturaleza, representados en dos casos, la cordera y el lobo, las aves y las sierpes, a los que se suma el de la destinataria. Se formula un enunciado básico, en el que el adynaton se equipara a la unión aberrante: «Materia diste al mundo de esperanza / de alcanzar lo imposible y no pensado / y de hacer juntar lo diferente» (vv. 155-157), respuesta a la doble pregunta: «¿Qué no se esperará de aquí adelante, / por difícil que sea y por incierto, / o qué discordia no será juntada?» (vv. 141-143), de la estancia anterior. Esta nueva ley, inferida del comportamiento de Galatea, da objetividad al conflicto personal, trascendido a través de la fama: «quitándolo de mí con tal mudanza, / que siempre sonará de gente en gente» (vv. 159-160). Se mide así la traición a partir de sus consecuencias externas, tras las que se oculta el yo, que en la enumeración reaparece inmerso en esa ley única, como último exponente del mundo alterado. Por lo tanto, el paso de la fronte a la sirima marca el juego de tensiones y correspondencias entre los ámbitos personal y universal, sometidos a un mismo principio que depende de la voluntad de Galatea.

La muerte de la amada de Nemoroso afecta a un entorno pastoril que lo secunda sumándose a su planto con señales de duelo. Del mismo modo que Salicio postula a Galatea como causa de hipotéticas discordias, la transformación que ha destruido el paisaje se debe al dolor de Nemoroso por Elisa, desencadenante de alteraciones que, paradójicamente, demuestran la armónica compenetración del ganado y el campo con el pastor. Para reflejar este juego imitativo ${ }^{35}$, la estancia oscila de lo genérico a lo íntimo. Un pronombre, «nos» (v. 296), delata la implicación de la colectividad, representada por «el ganado» y «el campo» (vv. 296-298), sujetos de cláusulas negativas («nunca pace [...] ni acude»), que anteceden al enunciado: «no hay bien que en mal no se convierta

34 La enumeración de imposibles deriva de una larga tradición en la que se alinean las Bucólicas de Virgilio (I, vv. 59-66; VIII, vv. 27-28, 52-55), así como la Biblia (Isaías 11, 6-8; 65, 25). La mayor parte de estos ejemplos incluye la pareja del lobo y el cordero (cfr. S. Pérez-Abadín Barro, Aromas de leyenda de ValleInclán: paisaje, mito, representación bucólica, New York, Peter Lang, 2009, pp. 58-61).

35 Al calibrar la dimensión mimética de la égloga, Ly («Garcilaso: l’effet de naturel», pp. 150-151) ha reparado en las analogías semánticas nuevas que ofrece esta estrofa a través de la rima. 
y mude» (v. 299). El axioma se ilustra con dos ejemplos de esa metamorfosis que ha desfigurado el paisaje, basada en el reemplazo de contrarios, el trigo por la avena y las flores por los abrojos (vv. 300-306). Desde el plano externo se accede a la subjetividad, que contribuye a ese deterioro con su llanto (vv. 308-309).

Cada estancia formula un principio de alcance colectivo, «Materia diste al mundo», «Después que nos dejaste», que demuestra una enumeración de dos oppositi conjugados o enfrentados, conforme a la concordia discors («de hacer juntar lo diferente») o a la transformación («no hay bien que en mal no se convierta y mude»). Las series de contrarios se cierran con la presencia del yo, que justifica las anomalías del entorno como reflejo de su perturbación, en ambos casos manifestada con el llanto. No se ocultan las diferencias, que atañen al enfoque temporal, el futuro de los adynata frente al presente del deterioro, a las respectivas causas, la propia Galatea pero no Elisa, sino el dolor de Nemoroso por su pérdida, y el énfasis que se otorga a cada efecto resultante, la discordia y la compenetración.

\section{Estancias 10, 12 y 25}

De la estancia 10, emparejada con la 20, irradia otro vínculo hacia la 25, con la que comparte una común expresión del sufrimiento amoroso en términos líricos de alcance metafísico. En ambas el dolor ilimitado se iguala a la muerte, su único desenlace: «No hay corazón que baste, / aunque fuese de piedra [...] / que no se esté con llanto deshaciendo / hasta acabar la vida» (vv. 133-139), «El desigual dolor no sufre modo: / no me podrán quitar el dolorido / sentir si ya del todo / primero no me quitan el sentido» (vv. 348-351). La idea de desposesión cristaliza en imágenes de desgarro asociadas a la muerte, término del llanto que produce en Salicio la visión de su hiedra «arrancada» (v. 136) y causa de las quejas de Nemoroso, que culpa a la «muerte arrebatada» (v. 344) de haberle despojado de Elisa, aplicando a su sentimiento la simbología del símil del ruiseñor: «ella en mi corazón metió la mano / y de allí me llevó mi dulce prenda» (vv. 341-342). Con ambas se relacionan los siguientes versos de la estancia 12, dirigidos contra Galatea: «dando a quien diste el corazón malvado, / quitándolo de mí con tal mudanza» (vv. 158-159).

\section{Estancias 13 y 26}

El lamento recibe una tregua en estrofas parentéticas que se fijan en una anécdota cotidiana, basada en el tema de las riquezas del pastor o en las reliquias de la amada, 
que entretiene momentáneamente al hablante sin evitar la manifestación del dolor a través del llanto.

En la estancia 13 Salicio se jacta de sus méritos, entre los que cuenta sus posesiones materiales, su canto y su físico. Remedando el canto de Coridón de la bucólica II de Virgilio ${ }^{36}$, enumera sus riquezas (vv. 169-171), que aportan rusticidad al perfil cortés-petrarquista de su discurso. El elogio de sus cualidades musicales sirve de pretexto para citar a Virgilio, «el mantüano / Títero» (vv. 173-174), y, al parangonarse a él, reconocerlo como modelo. Mediante lítotes se procede a la alabanza de la propia belleza («No soy, pues, bien mirado, / tan disforme ni feo», vv. 175-176), que deriva en la contemplación del propio rostro en el espejo del agua, motivo narcisista que al evocar el mito clásico aporta una nota trágica que restablece el tono lamentatorio provisionalmente interrumpido ${ }^{37}$. A la autocomplacencia se une el desprecio del rival, aludido como «ese que de mí se está reyendo» (v. 180). Se revela así el auténtico sentido de este pasaje de vanagloria, tras el que emerge de nuevo el tema de los celos («itrocara mi ventura!», v. 181) y del llanto, en el estribillo.

Aunque la contemplación de los cabellos de Elisa renueva las lágrimas de Nemoroso por su pérdida, el acto de contarlos y atarlos le permite abstraerse de su dolor $^{38}$. Este contacto con las reliquias supone un pretexto de acercamiento a la amada, presente además en el discurso a través del vocativo y la segunda persona. Por otra parte, la visión de los cabellos desencadena los suspiros con que los enjuga del llanto, para transmitirles ese sentimiento, hasta volver a la calma. Frente a la estrofa narcisista de Salicio, este momento del discurso de Nemoroso parte de una tensa emotividad, manifestada en el llanto, para alcanzar un eventual consuelo en la acción rutinaria de ordenar y juntar los cabellos, tal como reconoce el cierre de la estrofa: «Tras esto el importuno / dolor me deja descansar un rato» (vv. 364-365). La estrofa siguiente

\footnotetext{
36 A su vez inspirado en los idilios VI, XI y xx de Teócrito. Morros (ed. cit., pp. 463-464) añade los ejemplos de Calpurnio (III), Nemesiano (II), Sannazaro y Cervantes. Puede sumarse a las posibles fuentes el fragmento de poesía pastoril de las Metamorfosis ovidianas (XIII, vv. 750-897), imitado por Soto de Rojas en su égloga II (Cabello Porras, op. cit., pp. 363-376). Al aducir sus bienes materiales, Salicio expone un concepto de felicidad terrena que rompe con el arquetipo petrarquista, anticipando la figura del peregrino de las Soledades gongorinas (cfr. J. Rodríguez Luis, «Algunos aspectos de la evolución de lo pastoril de Garcilaso a Góngora», Hispanófila, 22, 8 (1964), pp. 1-14, y, especialmente, J. Lara Garrido, «Un nuevo encuadre de las Soledades. Esbozo de relectura desde la economica renacentista», Calíope, 9, 2 (2003), pp. 5-34, que aplica al personaje el código de ideal de vida aristocrático renacentista).

37 Zimic, que percibe en esta actitud los síntomas de un narcisismo paranoico (op. cit., p. 11), insiste en la filiación ovidiana de la estancia e identifica a Salicio con Polifemo, que simboliza su egoísmo (op. cit., pp. 18-23).

38 Al principal modelo de la estancia, la prosa XII de la Arcadia (313-318), se unen otras influencias, como la Eneida (Iv, 693-705), propuesta por Cruz (op. cit., pp. 101-102), que advierte en el pasaje la técnica petrarquesca de integración de la propia historia de amor con la leyenda de Dido.
} 
desvela la inutilidad de esta catarsis, que precede a la plena visualización de la noche funesta del fallecimiento de Elisa (vv. 366-379).

A través del llanto, la estancia 26 enlaza con el núcleo de Salicio, unificado por el estribillo «Salid sin duelo, lágrimas, corriendo». Incluso puede establecerse la equivalencia semántica de algunos fragmentos: «Mas ¿qué vale el tener, si derritiendo / me estoy en llano enterno?» (vv. 194-195), «y de un dolor tamaño / enternecer me siento que sobre ellos / nunca mis ojos de llorar se hartan» (vv. 355-357).

\section{Estancias 14 y 28}

Casi al final del canto una estrofa acumula efectos expresivos de valor patético, a modo de anuncio de la proximidad de la resolución. Las imprecaciones dirigidas contra Galatea o contra Lucina en modo interrogativo se sitúan en ese momento culminante, tras el cual el pastor alcanzará la serenidad con la renuncia o la visión anticipada de la apoteosis.

Aunque los reproches se distribuyen a lo largo de todo el canto de Salicio, adquieren especial intensidad en la estrofa 14, compuesta por una sucesión de preguntas. Las tres primeras se disponen anafóricamente, compartiendo la partícula interrogativa y el pronombre átono te, con el que se conjuga algún indicio de la persona hablante, en el verbo («te vine», v. 183; «te fui», v. 184) o en el pronombre, si el verbo está en tercera persona («te faltó en mí», v. 185). Un breve segmento preposicional o adverbial delimita el centro de estos versos consecutivos, para establecer entre ellos un paralelismo rítmico, reforzado por la anáfora:

$$
\begin{aligned}
& \text { ¿Cómo te + verbo + en tanto + sust.? } \\
& \text { ¿Cómo te + verbo + tan presto + adj.? } \\
& \text { ¿Cómo te + verbo + en mí + sust.? }
\end{aligned}
$$

La evidencia del rechazo de Galatea se impone en el ánimo de Salicio, que protesta a través de las preguntas por su menosprecio, aborrecimiento e indiferencia. A estas actitudes se opone una hipotética estima que la «condición terrible» de Galatea convierte en irreal (vv. 186-188). Esta insistencia en la propia valía, injustamente ignorada, deriva de la autocomplacencia exhibida en la estrofa anterior, de la que se retoma también el motivo de las riquezas del pastor, dueño de ovejas «sin cuento» que se desplazan de Cuenca a Extremadura (vv. 189-193). El giro interrogativo «¿No sabes» (v. 189) exige un reconocimiento que ni el mismo hablante se concede a sí mismo, 
ya que la respuesta enfatiza la inutilidad de sus dones: «Mas ¿qué vale el tener, si derritiendo / me estoy en llanto eterno?» (vv. 194-195) ${ }^{39}$.

El correlato de esta estancia en el canto de Nemoroso se sitúa en las recriminaciones interrogativas a Lucina ${ }^{40}$, que reemplaza a Elisa como destinataria cuando el lamento de tono epidíctico se convierte en discurso imprecatorio, apenas perceptible previamente en las quejas contra el hado y la muerte (estrs. 18 y 25). Ahora el movimiento interrogativo ocupa casi la totalidad de la estancia, repartida entre dos versos anafóricos, de idéntico esquema sintáctico («¿ĺbate tanto en [...]?»), más una amplia cláusula que prolonga hasta casi el final de la estancia una pregunta en vituperio de la diosa por su impasibilidad («¿Cosa pudo bastar a tal crüeza, / que, conmovida a compasión, oído / a los votos y lágrimas no dieras [...]?», vv. 382-391) ${ }^{41}$. Mientras que en este tramo interrogativo la acusación aparece atenuada por la forma negativa («oído / a los votos y lágrimas no dieras, / por no ver hecha tierra tal belleza, / o no ver la tristeza», vv. 383-386), la exclamatio final declara abiertamente: «¡Y tú, ingrata, riendo / dejas morir mi bien ante mis ojos!» (vv. 392-393)42. El vocativo, el epíteto descalificador y la imagen de crueldad inferida del contraste entre «riendo»y «morir» se suman para refrendar esa culpabilidad, al mismo tiempo que se declara por última vez el propio dolor, pues tras este intenso desahogo afectivo el lamento dejará paso a la proclamación de la apoteosis.

Estas estrofas concentran en la interrogación múltiple el valor patético del canto que las precede. En las primeras preguntas, la anáfora realza la desesperación e incredulidad, matices también perceptibles en la central, que añade el reproche, en una estructura que rompe el paralelismo de las cláusulas anteriores para plantear un enunciado irreal, que deriva de la «condición terrible» de Galatea (v. 186) y de la falta de compasión de Lucina (v. 383), culpables de la soledad del hablante: «y no viera este

\footnotetext{
39 Fragmento exclamativo en la edición de Rivers (p. 283).

40 El sentido del «trance de Lucina» de la estrofa 27 es matizado por S. Lipmann («On the significance of the 'Trance de Lucina' in Garcilaso's First Eclogue», Neophilologus, 67 (1983), pp. 65-70), en su reflexión sobre el proceso psicológico e imaginativo de Nemoroso. Véase también I. Colón, «Hacia una visión lírica de la realidad: la invocación de Lucina», en J. Ponce Cárdenas e I. Colón Calderón, eds., Estudios sobre tradición clásica y mitología en el Siglo de Oro, Madrid, Ediciones Clásicas, 2002, pp. 73-82. Juno y Diana comparten el epíteto Lucina, tal como advierte Herrera (Anotaciones, p. 734). Pero Juno Lucina, por personificar el ciclo lunar y presidir los nacimientos, se aproxima más a la Ártemis griega o Diana (P. Grimal, Diccionario de mitología griega y romana, Barcelona, Paidós, 1984, p. 298), la diosa cazadora prefigurada en la estrofa 28. Con la referencia a las aficiones cinegéticas de Nemoroso (vv. 388-391) reaparece un motivo presentado en el exordio, a propósito del destinatario (vv. 15-20), como nota Segre (op. cit., p. 165).

${ }^{41}$ Filomena responde al canto «a compasión movida» (v. 233, estr. 17), frente a Lucina, que no se mostró «conmovida a compasión» (v. 383).

42 Estas palabras finales se corresponden con el comienzo de la estancia 16, en la que Salicio asume la pérdida definitiva de Galatea debida a su falta de compasión: «Mas ya que a socorrerme aquí no vienes» (v. 211).
} 
triste apartamiento» (v. 188) ${ }^{43}$, «o no ver la tristeza / en que tu Nemoroso / queda» (vv. 386-388). Finalmente, se asume el fracaso de la protesta, mediante una inflexión lírica que implica la derrota definitiva: «Mas ¿qué vale el tener, si derritiendo / me estoy en llanto eterno?» (vv. 194-195), «iY tú, ingrata, riendo / dejas morir mi bien ante mis ojos!» (vv. 392-393).

\section{Estancias 15 y 24, 27}

El reflejo del dolor en el entorno se plasma como voz órfica en la penúltima estancia del canto de Salicio y en dos pasajes del canto de Nemoroso (estrs. 24 y 27). Se recrea así uno de los factores metapoéticos del exordio y de la transición, representado en el arrobamiento de las ovejas al escuchar a los pastores (vv. 4-6) y en la conmiseración del monte y de Filomena, que se hacen eco del lamento de Salicio (vv. 228-234). Para evocar la figura de Orfeo, el hablante se inviste de la facultad de conmoción de la naturaleza, viva e inerte, equiparando voz y lira del cantor mítico con el lamento ${ }^{44}$. La estructura sintáctica paralelística plasma esa armonía en cuatro cláusulas emanadas del sintagma que preside la estrofa, «Con mi llorar». En cada una de ellas el sujeto gramatical designa al elemento de la naturaleza que muestra su afección en el verbo correspondiente. Como es habitual en el empleo del recurso, el isocolon admite un margen de variación que sin alterar la homogeneidad evita la monotonía:

Con mi llorar + suj. (las piedras / los árboles / las aves / las fieras) + v. (enternecen y quebrantan / se inclinan / se condolecen y me adivinan / dejan)

El esquema general se diversifica en cuatro realizaciones:

$$
\begin{aligned}
& \text { suj. + v. + cd. + y + cd. + v. (el segundo complemento es un pronombre átono) } \\
& {[\mathrm{v} .+ \text { +] suj. + v. (esta cláusula se integra dentro de un verbo impersonal, parece) }} \\
& \text { suj. (det. + sust. + cláus.) + ccirc. + v. + y + cd. + ccirc. + v. } \\
& \text { suj. (det. + sust. + cláus.) + v. + cd. + ccirc. }
\end{aligned}
$$

\footnotetext{
43 Este verso también se relaciona con: «que había de ver, con largo apartamiento, / venir el triste y solitario día» (estr. 21, vv. 285-286).

44 Para la comparación de este canto órfico con ejemplos petrarquescos, véase Cruz (op. cit., pp. 102106). Además de Orfeo, subyacen en la estancia otros cantores míticos asiduos de las Bucólicas, tales como Anfíon (II, v. 24), Aríon (VIII, v. 56) y Lino (IV, vv. 56-57; vI, v. 67). A la estancia se suman otros pasajes garcilasianos, como el soneto xv y el exordio de la Ode ad florem Gnidi. Entre sus imitaciones, puede destacarse el lamento de Fenixardo, por celos, en la Égloga cuarta de Soto de Rojas (Cabello Porras, op. cit., pp. 390-391).
} 
El verbo, connotador del efecto del llanto, se duplica en las cláusulas primera y tercera: en un caso, el complemento común contrasta con el sentido de los dos verbos («enternecen / su natural dureza y la quebrantan», vv. 197-198); en otro, a la reacción pasiva («con diferente voz se condolecen», v. 201) se añade la capacidad de respuesta, con valor premonitorio («mi morir cantando me adevinan», v. 202). Los sujetos siguen una gradación a través de los órdenes de la naturaleza: la materia inerte, las piedras; el reino vegetal, los árboles, y los animales, aves ${ }^{45}$ y fieras. En los dos últimos, una cláusula de relativo enfatiza la sensibilidad de estos seres ante el llanto, que acompañan con los gorjeos propios o simplemente escuchan.

A lo largo de este tramo órfico, los indicios gramaticales de la primera persona, en forma del pronombre átono me con valor dativo o del determinante posesivo mi, se infiltran para recalcar una presencia dominante desde su arranque, «Con mi llorar». A este sintagma inicial remite el «contra mí» (v. 207) de la segunda parte de la estancia, que a la empatía mostrada por el entorno opone la impiedad de la amada, en forma de correspondencia antitética que une los versos «Con mi llorar las piedras enternecen / su natural dureza» (vv. 197-198) y «tú sola contra mí te endureciste» (v. 207). A modo de epítome, la declaración «los ojos aun siquiera no volviendo» (v. 208) confirma esa actitud, que ahora se enlaza con el motivo de las lágrimas reiterado a lo largo del canto en el estribillo.

Aunque las resonancias órficas se perciben en toda la égloga, en la que se suceden variaciones sobre la capacidad de respuesta del universo bucólico al canto de los pastores, de la estancia comentada emanan dos pasajes pertenecientes al núcleo de Nemoroso. En un caso, los astros nocturnos actúan como confidentes de las quejas del ruiseñor, que escuchan y comprenden: «y la callada noche no refrena / su lamentable oficio y sus querellas, / trayendo de su pena / el cielo por testigo y las estrellas» (vv. 334-337) ${ }^{46}$. Se igualan así a los oyentes del «llorar» de Salicio. De forma más evidente, las facultades órficas se asignan a las súplicas de Elisa, en un planteamiento hipotético

\footnotetext{
45 Las aves intervienen en la égloga con múltiples valores: en una enumeración como parte de la naturaleza («las aves y animales y la gente: / cual por el aire claro va volando», vv. 73-74; «las simples aves sin rüido», v. 164); como augurio («la siniestra corneja», v. 110) y, sobre todo, como confidentes cuya capacidad empática deriva de sus facultades musicales: «las aves que me escuchan, cuando cantan, / con diferente voz se condolecen / y mi morir cantando me adevinan» (vv. 200-202), «la blanda Filomena, / casi como dolida / y a compasión movida, / dulcemente responde al son lloroso» (vv. 231-234), [el ruiseñor] «y aquel dolor que siente, / con diferencia tanta, / por la dulce garganta / despide» (vv. 331-333). Nótese la acepción musical en «diferente» $\mathrm{y}$ «diferencia», frente al sentido del término en «que mayor diferencia comprehendo» (v. 166).

46 Estos versos dejaron su impronta en los poemas nocturnos de Figueroa, Herrera y Francisco de la Torre, que desarrollaron el valor connotativo de la noche y su función de confidente, plasmada en el discurso a través de la segunda persona. Sin duda los sonetos de Francisco de la Torre constituyen el principal exponente de las posibilidades semánticas y estructurales del escenario nocturno (cfr. S. Pérez-Abadín Barro, Los sonetos de Francisco de la Torre, University of Manchester, 1997, pp. 73-76, 131-133).
} 
que anuncia su inutilidad: «y aquella voz divina, / con cuyo son y acentos / a los airados vientos / pudieran amansar» (vv. 372-375).

\section{Estancias 16 y 29}

El final de cada uno de los cantos vislumbra un cambio de escenario para simbolizar la superación del dolor asociado al locus amoenus del pasado. Si Salicio renuncia al lugar como prueba de generosidad hacia su antigua amada, Nemoroso lo sublimará en el ámbito de la felicidad perpetua junto a Elisa. De forma complementaria, ambos han inspirado su evocación de los pasados amores en un entorno cuyas funciones serán anuladas o trascendidas al evolucionar la situación emocional del pastor. Se confirma así la implicación afectiva del paisaje que, más allá del marco, ha prestado a las quejas un oyente activo, vicario de la presencia de la amada.

Salicio accede a su nuevo estado espiritual legando a Galatea ese prado, testigo de sus pasados amores. La triple reiteración del ofrecimiento involucra a cada una de las personas gramaticales del triángulo amoroso: a la amada en «no dejes el lugar que tanto amaste» (v. 212); al propio hablante en «Yo dejaré el lugar do me dejaste» (v. 214); al rival en «no es mucho que el lugar también le quede» (v. 224). El deíctico de proximidad aquí, repetido cinco veces, se combina con el verbo para reforzar el valor mostrativo, en el que se insiste mediante la anáfora (ves aquí + fn. $)^{47}$, en tres cláusulas consecutivas que describen el locus amoenus: "Ves aquí un prado lleno de verdura, / ves aquí una espesura, / ves aquí un agua clara» (vv. 216-218) ${ }^{48}$. A la dimensión espacial de la estancia contribuyen los verbos de movimiento («vienes», v. 211; «dejes», v. 212; «venir», v. 213; «dejaré», «dejaste», v. 214; «ven», «detienes», v. 215; «alejo», v. 221). Por lo tanto, la propuesta de Salicio se traduce en nociones locativas, basadas en

\footnotetext{
47 La reiteración del deíctico, tal vez inspirada en el cuádruple hic de la bucólica x (vv. 42-43), interviene con frecuencia en las descripciones de paisajes idílicos, moradas celestiales o Paraísos, tal como ilustran la égloga de Acuña «Con nuevo resplandor» (vv. 37-69), la oda vIII (vv. 66-75) de Fray Luis de León, el canto xIII del Crótalon y los capítulos I, L del Quijote y III, 18 del Persiles, explicados en S. Pérez-Abadín Barro («El modelo dramático pastoril en las églogas de Hernando de Acuña», en G. Cabello Porras y S. Pérez-Abadín Barro (eds.), Huir procuro el encarecimiento. La poesía de Hernando de Acuña, Santiago de Compostela, USC Editora, Académica, 2011, pp. 189-243 [194-196]).

48 Versos que se suman a la serie de pinceladas dispersas del paisaje pastoril, en las estancias 4: «al pie de una alta haya, en la verdura / por donde una agua clara con sonido / atravesaba el fresco y verde prado» (vv. 46-48); 8: «selva umbrosa», «solitario monte», «verde hierba», «fresco viento», flores y primavera (vv. 99-104); 18: «Corrientes aguas puras, cristalinas, / árboles que os estáis mirando en ellas, / verde prado de fresca sombra lleno», aves y hiedra (vv. 239-244); 21: «cuando en aqueste valle al fresco viento / andábamos cogiendo tiernas flores» (vv. 283-284), «otros montes y otros ríos, / otros valles floridos y sombríos» (vv. 403-404).
} 
la identificación del abandono del lugar con la renuncia a Galatea, que renovará la simbología del escenario con su nuevo amor ${ }^{49}$.

El sentido negativo de las últimas palabras de Salicio se invierte en la estancia 29, dedicada a la proclamación de la apoteosis de Elisa en un locus amoenus alternativo, que sustituirá al actual para restablecer la armonía amorosa truncada por la muerte. El paisaje bucólico se confunde entonces con un espacio ultraterreno situado en «la tercera rueda» (v. 400), correspondiente a la esfera de Venus, significativamente elegida como reino del amor, al mismo tiempo que evoca las moradas de los bienaventurados consagradas por las tradiciones grecolatina y cristiana ${ }^{50}$ : «y en la tercera rueda, / contigo mano a mano, / busquemos otro llano, / busquemos otros montes y otros ríos, / otros valles floridos y sombríos» (vv. 400-404). Esta visualización augura un reencuentro con Elisa, tras el abandono del valle del presente en el momento de la muerte, contemplada como una liberación del velo del cuerpo. La renuncia al lugar, que Salicio plantea desde una perspectiva estoica ${ }^{51}$, adquiere en Nemoroso matices ascéticos, derivados de un rechazo del mundo a causa de la pérdida de Elisa, término último de las aspiraciones de trascendencia cifradas en el amor ${ }^{52}$.

\footnotetext{
49 Para Segre (op. cit., pp. 189-190), en la estrofa se entrevé la muerte de Salicio, del mismo modo que el epílogo alude a un viaje a los reinos de la muerte.

50 Tal como señala Herrera (Anotaciones, pp. 737-738), que lo aplica en un verso de su égloga Amarilis («o estés con Venus en el cielo», v. 295). También en la oda IV de Fray Luis de León es mencionada la diosa «de la tercera rueda» (vv. 24-25). En el sistema de nueve cielos establecido por Tolomeo en el Almagesto, el tercero corresponde al círculo de Venus, en el que también transcurren los cantos VIIII y IX del Paradiso de Dante, como recuerda O. H. Green (España y la tradición occidental, Madrid, Gredos, vol. 1, 1968, pp. 191-194), que explica cómo Nemoroso imagina a «Elisa descendiendo del Empíreo inmóvil para encontrarse con él en el círculo de la celeste Venus» (op. cit., vol. 2, 1969, p. 49), del mismo modo que en el Paradiso dantesco los espíritus acuden a recibir al poeta. La estrofa podría asimismo relacionarse con el Paraíso Terrenal o Jardín del Edén del Purgatorio (XXVIII-XXXIII), único escenario bucólico de la Commedia (cfr. Poggioli, op. cit., pp. 135-152). Se han señalado como fuentes fundamentales de este pasaje garcilasiano el canto de Menalcas de la bucólica v, el soneto cccir de Petrarca, que sitúa a Laura en un cielo neoplatónico, la égloga v de la Arcadia y la piscatoria I, Phyllis, de Sannazaro (Bayo, op. cit.; Bocchetta, op. cit.; Lapesa, op. cit.; Cruz, op. cit.; Morros, ed. cit.; Gargano, «Il lugar di Garcilaso», que profundiza en las conexiones con poemas del Canzoniere que Garcilaso reformula en sentido laico). Podría añadirse la égloga III de Bernardo Tasso, que ofrece la visión celeste del difunto en los círculos de Venus o de Marte (vv. 49-61) y expresa el deseo de reencuentro tras la muerte (vv. 76-79), idea también presente en la égloga vII (vv. 25-29).
}

51 El estoicismo en otras composiciones de Garcilaso es tratado por Morros (ed. cit., pp. LXXXI- LXXXV). Zimic (op. cit., p. 13), que atribuye a Salicio el mezquino propósito de avivar el remordimiento de Galatea, se opone a esta idea de renuncia y rebate asimismo la interpretación neoplatónica del amor del pastor, defendida, entre otros, por A. Parker («Tema e imagen en la égloga I de Garcilaso», en E. L. Rivers (ed.), La poesía de Garcilaso. Ensayos críticos, Barcelona, Ariel, 1975, pp. 197-208).

52 Frente a la «apoteosis cristiana» que propone Bayo (op. cit., p. 100), la estancia se cimenta en una concepción clásica de ese cielo que la amada pisa «con inmortales pies» desde una posición privilegiada que le permite dominarlo, al igual que Dafnis en la bucólica v, que inspira los versos iniciales: "Candidus insuetum miratur limen Olympi / sub pedibusque uidet nubes et sidera Daphnis» (vv. 56-57) [«Lleno él de luz, el umbral insólito admira del cielo / Dafnis y puede mirar a sus pies las estrellas y nubes»]. Como nota Leclercq (op. cit., p. 702), los versos virgilianos remiten a las nociones cosmográficas expuestas en Fedón (108c-111c) y Timeo (71b), que describen las regiones supraterrenas desde las que se 
Atisbos de esta particular ética ya se percibían en la estancia 21, en la que Nemoroso expresaba sus ansias de muerte y liberación del mundo, manifestadas en imágenes de oscuridad y prisión: «y lo que siento más es verme atado / a la pesada vida y enojosa, / solo, desamparado, / ciego, sin lumbre en cárcel tenebrosa» (vv. 292-295). Ese estado sobreviene a una etapa de felicidad, en el mismo espacio y en compañía de Elisa. El lugar de entonces, «aqueste valle» (v. 283), en el que ambos recogían flores, será relevado por «otros valles floridos y sombríos» (v. 404), previstos en la existencia futura.

\section{Final: conclusiones, esquemas y resultados}

Cada uno de los cantos sirve de cauce a un análisis del sentimiento amoroso, que evoluciona desde el reflejo del profundo dolor hasta su superación, a través de un proceso afectivo que comporta un razonamiento transmitido al entorno y a la propia amada ausente, por parte de un yo disociado que recupera su identidad al asumir su infortunio con resignación o con esperanza de trascendencia. La cohesión narrativa y espiritual de cada soliloquio se plasma en un desarrollo marcado por la continuidad, sintáctica o semántica, de las estrofas, que se agrupan en parejas o en series, sin que falten cambios abruptos demarcadores del paso a una nueva fase de reflexión.

Tras haber sido presentado por el narrador, Salicio emite en soledad un canto en el que se suceden las quejas (estrs. 5-7), una armónica evocación (estr. 8), las premoniciones (estrs. 8-9), la visualización de Galatea junto a un rival, en el centro del lamento (estrs. 10-12) y dentro de la serie de adynata (estrs. 11-12), la autojactancia de los méritos propios (estrs. 13-15), que incluyen las facultades órficas, inútiles con Galatea (estr. 15), y, en la estrofa final, la renuncia definitiva al lugar y a la amada (estr. 20).

La estrofa de enlace establece el orden de las intervenciones, cediendo el turno a Nemoroso, que toma la palabra para manifestar su dolor en un parlamento autónomo, aunque simulado como respuesta al precedente. Al configurarse como lamento funeral, esta sección gravita sobre la idea de pérdida, aceptada con melancolía en relación al valle que permanece como escenario (estrs. 18-19), la propia amada desaparecida (estrs. 20-21), el duelo universal (estr. 22), los símiles del transcurso del día y del canto del ruiseñor, extraídos del entorno (estrs. 23-25), la contemplación de las reliquias

ve el resplandor del cielo y de los astros. Cfr. para la idea de paganización, aunque a través del canto, la Égloga de las hamadríades de Barahona de Soto (J. Lara Garrido, «Las églogas», en La poesía de Luis Barahona de Soto (Lírica y Épica del Manierismo), Diputación Provincial de Málaga, 1994, pp. 238-268 [252-260]). 
(estr. 26), el recuerdo de la tragedia atribuida a la negligencia de Lucina (estrs. 27-28) y, como desenlace, la apoteosis y futura reunión con Elisa (estr. 29).

La neutralización de las coordenadas espacio-temporales motiva el aislamiento de los cantos, solo engarzados por una voz narrativa que omite referencias al contacto o intercambio de los roles dialógicos de los pastores, coincidentes en un día indefinido y en un lugar emblemático, que actualiza su significado como fondo pastoril. Considerados de forma aislada, ambos discursos describen un movimiento de separación resuelto en convergencia cuando el ocaso anuncia el fin del canto y del pastoreo. Aunque el narrador establece el orden en la transición («Aquí dio fin a su cantar Salicio», v. 225; «Lo que cantó tras esto Nemoroso», v. 235), las indicaciones del epílogo («Nunca pusieran fin al triste lloro / los pastores», vv. 408-409) sugieren simultaneidad de ejecución en diferentes rincones de ese monte que actúa como oyente único de ambas recitaciones (v. 410). Salicio no ha contado a Nemoroso sus males, sino a una Galatea ausente y al paisaje, del mismo modo que Nemoroso emite su planto funeral mentando a la desaparecida Elisa y, en tono recriminatorio, a los agentes culpables de su muerte.

Por lo tanto, la configuración dialógica radica en los ecos verbales, estructurales y temáticos, que determinan la equivalencia y complementariedad de los cantos. Dos versiones alternativas del amor desgraciado se someten a un proceso catártico en la comunicación con la naturaleza, que brindará el remedio para superar el dolor, imponiendo la ley del equilibrio universal rector de todos sus órdenes. La mujer cruel y la amada divina, los celos y la muerte, el reproche y el lamento, el rival y el destino aciago, la renuncia y la trascendencia resumen, en forma de binomios, ese antagonismo que deviene identificación. Los casos amorosos se reducen a un sentido unitario del que se desprende el mensaje moral de la caducidad de las pasiones humanas para proponer dos vías distintas de superación.

El siguiente esquema sintetiza las principales reiteraciones intrapoemáticas que imprimen a la égloga su característico movimiento pendular:

\section{Narrador}

estrs. 1-4

estrs. 17 y 30

la naturaleza escucha el canto / llanto referencias metapoéticas

espacio y tiempo bucólicos 


$$
\begin{gathered}
\text { enunciado de la causa } \\
\text { deseo de muerte }
\end{gathered}
$$

estr. 6

$$
\text { priamel / símil }
$$

contraste noche-sol, sombra-luz, en relación al yo

estr. 23

estr. 8

estrs. 18-19

locus amoenus: recuerdos gratos

la soledad complace al pastor

estr. 9

estr. 19

sueño

durmiendo en la floresta / en el valle

estr. 10

estr. 20

$$
\begin{gathered}
\text { claros ojos, imagen física, desposesión } \\
\text { interrogatio: ubi sunt?: } \\
\text { con otro (Galatea) / bajo tierra (Elisa) }
\end{gathered}
$$

estr. 12

estr. 22

$$
\text { mundo al revés }
$$

(consecuencia de la infidelidad / de la muerte)

estrs. 10, 12

estr. 25

definición lírico-metafísica del sufrimiento amoroso idea de desposesión y desgarro

estr. 13

estr. 26

$$
\begin{aligned}
& \text { interludio: cese del llanto } \\
& \text { riqueza / reliquias }
\end{aligned}
$$

estr. 14

estr. 28

reproches en modo interrogativo

(a Galatea / a Lucina-Diana)

estr. 15

la naturaleza refleja el dolor tema órfico 
estr. 16

estr. 29

cambio de escenario

superación del amor pastoril

Estas recurrencias actúan a modo de temas cardinales, cuya mutua remisión dota al poema de un movimiento retroactivo de efecto especular, al que contribuyen otras conexiones menos evidentes pero asimismo eficaces:

estr. 2

estr. 28

la caza

estr. 4

estr. 18

«verde prado», árboles, agua

estr. 4

estr. 24

«él, con canto acordado / al rumor que sonaba / del agua que pasaba» «que a su canto el aire suena»

estr. 5

estr. 20

vasallaje amoroso

estr. 6

estr. 27

«siempre está en llanto esta ánima mezquina» «que siempre aflige esta ánima mezquina»

estr. 7

estr. 27

enálage, obsecratio, muerte

estr. 8

estrs. 19,25

inflexión exclamativa medial

(auersio)

estr. 8

estr. 20

«la desventura mía»

«por desventura mía»

estrs. 10-11

estrs. 20-21

sucesivas interrogationes

estr. 14

estr. 21

«y no viera este triste apartamiento»

«que habia de ver, con largo apartamiento» 
estr. 14

estr. 26

«derritiendo / me estoy en llanto eterno» «enternecer me siento [...] nunca mis ojos de llorar se hartan»

estr. 15

estr. 24

las aves «cuando cantan, / con diferente voz se condolecen» el ruiseñor «aquel dolor que siente, / con diferencia tanta, [...] despide»

estrs. 15-16

estrs. $27-28$

falta de compasión

estr. 17

estr. 24

Filomena, ruiseñor

estr. 17

estr. 28

Filomena «a compasión movida»

Lucina, no «conmovida a compasión»

El canto de Nemoroso registra en su interior ecos temáticos indicativos de su trabazón discursiva. Además del emparejamiento de las estrofas que amplifican o contrastan un mismo motivo, como el valle (18-19), la pregunta a Elisa (20-21), el símil del ruiseñor (24-25) y los reproches a Lucina (27-28), ciertas reiteraciones conectan pasajes distantes para dibujar una imagen unitaria del canto, que reitera los siguientes elementos: el valle en sus distintas fases temporales, del pasado, del presente y del futuro (estrs. 18, 19, 21, 29); el despertar junto a Elisa, como recuerdo y como visión, ligados al reposo de su presencia (estrs. 19, 29); la imprecación al hado, a la muerte y a Lucina (estrs. 18, 25 y 28); el rechazo de las ataduras mundanas y el afán de una existencia ultraterrena (estrs. 21, 29).

El análisis estructural de la égloga, que sumarizan los esquemas precedentes ${ }^{53}$, demuestra que el primer canto condiciona el segundo en la selección de topoi poéticos,

\footnotetext{
53 Pueden recordarse, entre otros, los trabajos de Guillén (op. cit., pp. 182-192), acerca de las polaridades que la vertebran y definen su dinámica pastoral; Ghertman (op. cit.), que opone los cantos por su modelo sintáctico, de convergencia y divergencia, respectivamente, así como sus relaciones interestróficas en parejas, alternancia o concatenación; Segre (op. cit., p. 163), que describe el poema como «un díptico, en el que se realiza una serie bien calculada de afinidades y desemejanzas»; Cruz (op. cit., pp. 96-97), que repara en su paralelismo estructural y temático. No faltan propuestas de asociaciones estróficas concretas: 10 y 20, 14 y 28 (Woods, op. cit.); 14 y 27-28 (Ghertman, op. cit., p. 116); 1-3 y 28, 6 y 23, 8 y 21 (Segre, op. cit.); 9 y 26, 6 y 27, 13 y 28 (Lipmann, op. cit., p. 68); 8-16 y 18-29 (Gargano, «'Questo nostro caduco et fragil bene'»). Determinadas lecturas aproximan ambas secciones a partir de la desmitificación del canto de Nemoroso (Ter Horst, op. cit.; Gallagher, «Hacia una poética de Garcilaso: la subversión de la armonía en su arte; apuntes sobre la 'Égloga primera'», Cuadernos Hispanoamericanos, 319 (1977), pp. 113-124; Lipmann, op. cit.). Añádase, fundamentalmente, la filiación que establece Lara Garrido («Poética del género bucólico y ekphrasis en la Égloga de Pilas y Damón», en De saber poético y verso peregrino. La invención manierista en Luis Barahona de Soto, Universidad de Málaga, 2002, pp. 297-429 [385-391]) entre
} 
el proceso psicológico y el significado global, delineando un recorrido dialéctico que responde al trazado de la $\mathrm{Y}$ pitagórica, a modo de bivium de sendas paralelas, cada uno de los dos casos amorosos, no desprovistos del sentido moral inherente a la imagen clásica $^{54}$. Desde tal perspectiva, a la solución terrena y negativa del sapiens estoico se contrapone la del sophós platónico, que espera la inmortalidad bienaventurada en las sedes quietae. La bifurcación del desenlace proyecta una lectura perspectivista sobre la materia común, el amor desgraciado, resuelto en el futuro en dos extremos, tormento y gloria, sin posibilidad de convergencia ${ }^{55}$.

Esta idea se esclarece a tenor de los esquemas precedentes, que arrojan otros obvios resultados:

1. La voz ficcional del poeta crea un marco narrativo que se disgrega en tres núcleos trabados entre sí (estrs. 1-5, 17 y 30), para delimitar con nitidez las dos secciones complementarias albergadas en su interior.

2. Numerosas estancias del primer soliloquio anuncian las del segundo, dotado así de un adicional sentido evocador.

3. La disposición de las estancias de cada canto (5-16 / 18-29) se corresponde, atendiendo a las recurrencias detectadas en el cuadro principal, que permite emparejarlas según este orden:

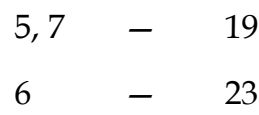

la bucólica v y la Égloga de Pilas y Damón de Barahona de Soto.

54 Esta peregrinatio arcádica hacia un paraíso perdido trasciende el ámbito del poema para abarcar el conjunto de tres églogas unidas por la coherencia temática y una progresión que permite reconstruir una trayectoria espiritual (cfr. E. L. Rivers, «Las églogas de Garcilaso: ensayo de una trayectoria espiritual», en Actas del I Congreso Internacional de Hispanistas, Oxford, Dolphin Book, 1964, pp. 421-427; «La paradoja pastoril del arte natural», en E. L. Rivers (ed.), La poesía de Garcilaso. Ensayos críticos, pp. 285308; Fernández-Morera, op. cit.; J. Gómez, «Sobre la teoría de la bucólica en el Siglo de Oro: hacia las églogas de Garcilaso», Dicenda, 10 (1991-1992), pp. 111-125; Madelpuech-Toucheron, op. cit.).

55 Como advierte J. L. Bouza Álvarez (Religiosidad contrarreformista y cultura simbólica del barroco, Madrid, CSIC, 1990, pp. 459-460), la dicotomía entre el camino áspero de la virtud y el holgado y ameno del vicio procede fundamentalmente de la moral pitagórica, aunque también guarda relación con el platonismo, el estoicismo y la Biblia (Mt. vII, 13-14). Se debe asimismo a los pitagóricos la doctrina de las sedes quietae, o morada celeste que proporcionará reposo a los bienaventurados (Bouza Álvarez, op. cit., p. 458). El Criticón, I, 5 de Gracián (ed. de S. Alonso, Madrid, Cátedra, 1996 pp. 120-121) y el Sueño del Infierno de Quevedo (Los sueños, ed. de I. Arellano, Madrid, Cátedra, 1991, pp. 172-173) suministran ejemplos de la doble senda o letra de Pitágoras, que cuenta con la guía de Mercurio, tal como se representa en un emblema de Alciato («Que hemos de ir por donde Dios nos llama», Los emblemas de Alciato. Traducidos en Rimas Españolas (1549), ed. de R. Zafra, Barcelona, José J. de Olañeta Editor y Universitat de les Illes Balears, 2003, p. 104). 


$\begin{array}{lll}8 & - & 18-19 \\ 9 & - & 19 \\ 10 & - & 20 \\ 12 & - & 22 \\ 10,12 & - & 25 \\ 13 & - & 26 \\ 14 & - & 28 \\ 15 & - & 24,27 \\ 16 & - & 29\end{array}$

Un anticipo (6-23) y leves retrocesos apenas alteran la equidistancia mantenida entre sendas unidades. Las pocas exclusiones $(11,21,24,27)$ afectan a estrofas supeditadas a otra ${ }^{56}: 11$ presenta los adynata de 12; 21 prosigue la interrogatio de 20; 24 introduce el símil descifrado en 25 y 27 las imprecaciones a Lucina. Por otra parte, su funcionamiento dentro de las conexiones secundarias justifica su relevancia estructural.

4. A diferencia del anterior, el segundo esquema recoge aquellas recurrencias dispuestas de modo aleatorio, pero igualmente operativas en su capacidad de crear entre los dos cantos ecos de motivos, expresiones y recursos, para corroborar así la sugestión de imagen desdoblada que se desprende del conjunto.

Sumadas a las deudas semánticas de la égloga con las quejas por celos de Damón y con el canto funeral, de duelo y apoteosis, que entonan por turnos Mopso y Menalcas, paradigmas respectivos de los discursos de Salicio y de Nemoroso, las recurrencias constatadas revalidan la factura virgiliana del poema de Garcilaso, que combina los diseños de las bucólicas v y viII para insinuar un movimiento circular de retornos y correspondencias, conforme al principio de la ringkomposition, signo de su clasicismo. Si la égloga de Damón y Alfesibeo proporciona las líneas divisorias y algunos motivos y fórmulas del exordio y la transición, el poema dedicado a Dafnis inspira la simetría de las intervenciones. Aunque el marco narrativo y el trazado superficial delatan mayor proximidad a la bucólica vIII, en esta amalgama de modelos estructurales corresponde la prevalencia a la bucólica v, paradigma del desarrollo responsivo que define la dispositio de la égloga I.

56 Para ilustrar la modalidad de relación interestrófica de stanza coupling, realizada como digresión o amplificación, en la terminología de Ghertman (op. cit.). 